\title{
Partitioning of water soluble carbohydrates in vegetative tissues of Lolium multiflorum Lam. ssp. italicum cv. Lema
}

\author{
Carla Zuliani Sandrin, Marisa Domingos and Rita de Cássia Leone Figueiredo-Ribeiro* \\ Instituto de Botânica, CP 4005, 01061-970, São Paulo, SP, Brazil; *Corresponding author: ritarib@usp.br
}

Received: 01/04/2006, Accepted: 12/06/2006

In temperate grasses, fructans are the major storage polysaccharides, being accumulated mainly in mature leaf sheaths, and also in the roots. The partitioning of carbohydrates within different organs regulates plant growth and development. The aim of the present work was to analyze the partitioning of water soluble carbohydrates in five different parts (elongating leaf blades, expanded leaf blades, upper and lower segments of the stubble, and roots) of plants of L. multiflorum cv. Lema, in order to contribute to an understanding of soluble carbohydrates distribution in these plants. Soluble carbohydrates and total fructose were analyzed in plants cultivated during 4 months in a glasshouse, by colorimetric, TLC and HPAEC-PAD techniques. Results showed that the greatest portion of total soluble carbohydrates was constituted of free and combined fructose, in all parts of the plants. The stubble contained the highest level of carbohydrates, followed by the elongating leaf blades, expanded leaf blades and roots. The leaf sheaths were not analyzed separately from the stubble, which explains the high levels of carbohydrates found in this part of the plant. The high metabolism of the elongating leaf blades, when compared to that of the expanded leaf blades, could explain the increased amounts of fructans stored in those tissues. Analysis by HPAEC-PAD showed that the elongating leaf blades and the roots had the highest proportions of low molecular weight fructans that could be readily mobilized, supplying the demand of growing tissues in other organs.

Key words: fructan, grass, Italian ryegrass, sugars.

Resumo: Partição de carboidratos solúveis em água em tecidos vegetativos de Lolium multiflorum Lam. ssp. italicum cv. Lema. Os frutanos são os polissacarídeos de reserva mais abundantes em gramíneas de clima temperado, sendo estocados principalmente nas bainhas de folhas adultas e também nas raízes. A partição de carboidratos entre os diferentes órgãos da planta regula seu crescimento e seu desenvolvimento. Visto que a partição de carboidratos solúveis ainda é desconhecida em Lolium multiflorum cv. Lema, o objetivo do presente trabalho foi verificar a partição desses carboidratos em cinco partes distintas (lâminas em alongamento, lâminas totalmente expandidas, segmentos superior e inferior do estolho e raízes) de plantas dessa espécie. Para isso, os carboidratos solúveis totais e a frutose total foram quantificados em plantas cultivadas durante quatro meses em Casa de Vegetação, por métodos colorimétricos e por TLC e HPAEC-PAD. Os resultados mostraram que grande parte da fração dos carboidratos solúveis totais é constituída por frutose, na forma livre e combinada, em todas as partes da planta. O estolho contém os maiores níveis de carboidratos, seguido pelas lâminas em alongamento, lâminas expandidas e raiz. No presente estudo, as bainhas foliares não foram diferenciadas do estolho, o que explica os altos teores de carboidratos solúveis encontrados nessa porção das plantas. As altas taxas de metabolismo das lâminas em alongamento, quando comparadas com as de lâminas expandidas, poderia explicar o maior acúmulo de frutanos nas primeiras. A análise por HPAEC-PAD mostrou que as lâminas em alongamento e as raízes apresentaram as maiores proporções de frutanos de baixo peso molecular, que podem ser mobilizados prontamente, atendendo à demanda de outros órgãos da planta.

Palavras-chave: açúcares, azevém, frutanos, gramíneas.

\section{INTRODUCTION}

A grass leaf is composed of the blade and the sheath, with the growing tissues being confined to its basal region, which is enclosed by the sheaths of older leaves. In temperate forage grasses, the water soluble carbohydrates (WSC) sucrose and fructans (oligo- and polyfructosyl sucrose) are the primary reserve of carbon in vegetative tissues (Cairns et al., 2002), being mainly stored in the leaf sheaths, that can accumulate up to $70 \%$ of total fructans (Thomas and James, 1999). The elongating leaf bases also synthesize fructans 
in substantial amounts despite acting as strong sinks for imported C assimilates (Schnyder and Nelson, 1987). But fructans are not homogeneously distributed in this growing tissue. Their highest content is found in the growth zone and decreases strongly in the differentiation zone (Roth et al., 1997).

Fructans are used for both long-term and short-term storage in grasses (Spollen and Nelson, 1994) and have three possible functions: (1) to supply energy, (2) to facilitate sucrose unloading from phloem, (3) to help to maintain an appropriate osmotic potential to ensure cell enlargement in the elongation zone. In addition to their accumulation in the elongating zone of the leaf, fructans are mainly stored in mature leaf sheaths and in roots when photosynthetic carbon supply exceeds demand for growth and development (Guerrand et al., 1996). Fructans are only accumulated in leaf blades when the storage capacity of both leaf sheaths and growth zones has already decreased (Guerrand et al., 1996).

Lolium species contain fructans of the inulin series, the inulin neoseries and the levan neoseries with polymers with $\beta(2-6)$ linked fructosyl residues on either end of the sucrose molecule (Bonnett et al., 1994). Fructans based on 1-kestotriose and 6G-kestotriose are accumulated in these species. The enzymatic activities responsible for the synthesis of both trisaccharides were found to be distributed longitudinally in expanding leaves of Lolium perenne (Pavis et al., 2001a), with low temperature and continuous illumination underlying the main differences found in different tissues (Bonnett et al., 1994). The partition of fructans within the plant is well known in Lolium perenne (Guerrand et al., 1996; Morvan-Bertrand et al., 2001; Pavis et al., 2001a,b), but not in the Italian ryegrass (Lolium multiflorum).

Lolium multiflorum is economically important and its use as a forage grass in many countries, including in South Brazil is well known (Marchezan et al. 2002). The cultivar Lema of this species is also used as bioindicator of air quality, due to its high capacity for accumulating metals, sulfur and fluorine when growing in the presence of these air pollutants (Domingos et al., 1998). Preliminary analyses showed that high molecular weight fructans accumulated in higher proportions in whole plants of L. multiflorum exposed to polluted sites, when compared with plants grown in a glasshouse with filtered air (Sandrin et al., 2004).

Considering that the partitioning of carbohydrates within different organs regulates plant growth and development, the understanding of fructan partitioning in plants of $L$. multiflorum is essential where the intention is to improve its productivity or its bioindicator efficiency.

So, the aim of the present study was to analyze the partitioning of water soluble carbohydrates in different parts of plants of Lolium multiflorum Lam. ssp. italicum Beck cv. Lema (elongating leaf blades, expanded leaf blades, upper stubble, lower stubble and roots) growing in a glasshouse environment, under subtropical climatic conditions and submitted to low levels of air pollution.

\section{MATERIAL AND METHODS}

During the winter of 2002, seeds of Lolium multiflorum ssp. italicum cv. Lema were sown into five plastic pots (1L) using the substrate Plantmax mixed with vermiculite (3:1). The plants were cultivated in a glasshouse at the Institute of Botany, São Paulo (Brazil), under very low levels of gaseous and particulate pollutants removed by filters, to avoid interferences of toxic elements from local air pollution on fructan metabolism. During cultivation, climatic conditions in the glasshouse were similar to those in São Paulo city. The mean values of temperature and humidity during the cultivation period in the glasshouse were $21.5^{\circ} \mathrm{C}\left(17.5^{\circ} \mathrm{C}\right.$ to $\left.26.3^{\circ} \mathrm{C}\right)$ and $66.7 \%(55.7 \%$ to $80 \%)$, respectively, and irradiance was $472 \mu \mathrm{mol} . \mathrm{m}^{-2}$. $\mathrm{seg}^{-1}\left(74 \mu \mathrm{mol} . \mathrm{m}^{-2} . \mathrm{seg}^{-1}\right.$ to 816 $\left.\mu \mathrm{mol} . \mathrm{m}^{-2} \cdot \mathrm{seg}^{-1}\right)$. The plastic pots equipped with nylon wicks were placed in deionized water basins covered with metal grating and black plastic foil, thus providing a continuous and sufficient water supply (Arndt and Schweizer, 1991). The grass cultures were defoliated periodically at $4 \mathrm{~cm}$ above ground level, to stimulate growth and tillering, and fertilized with the solution of Epstein (1975) without micronutrients (40 mL/pot). After six weeks, cutting and fertilization were interrupted and the plants continued to grow for a further 8 weeks. Plants of each pot were individualized and separated into five different parts corresponding to the elongating leaf blades, expanded leaf blades, upper stubble, lower stubble and roots, as schematically shown in figure 1 . Stubble refers to the plant compartment that includes both fully expanded leaf material (leaf sheaths), as well as basal immature parts of expanding leaves (elongating leaf bases).

Samples of each plant part, containing $2 \mathrm{~g}$ of fresh mass, were extracted three times in boiling $80 \%$ ethanol and once in hot distilled water for soluble carbohydrate extraction. Ethanol and water extracts were combined, evaporated to dryness under vacuum and resuspended in $4 \mathrm{~mL}$ of water. Total sugar and total fructose were quantified by the phenolsulfuric (Dubois et al., 1956) and anthrone methods (Jermyn, 


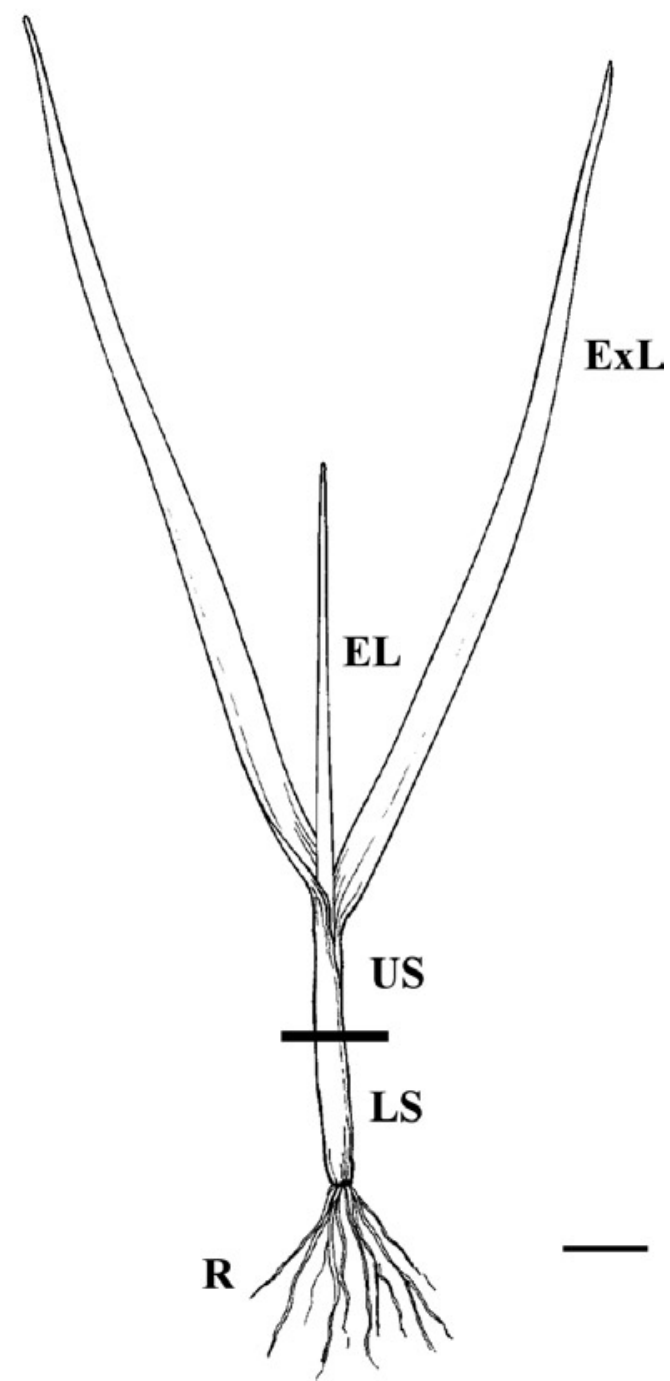

Figure 1. Schematic representation of four-month-old Lolium multiflorum plants. ExL = expanded leaf blades; EL = elongating leaf blades; US = upper stubble; LS = lower stubble and $\mathrm{R}=$ roots. $\mathrm{Bar}=1 \mathrm{~cm}$.

1956), respectively. Aliquots of the carbohydrate extracts were filtered through columns containing cation exchange resin, anion exchange resin and C18 modified silica (Waters, USA) to remove charged compounds, proteins, lipids and pigments (Smouter and Simpson, 1991). The columns were eluted with deionized water. After neutralization samples were concentrated under vacuum and dissolved in deionized water. Component sugars were separated by high-performance anion exchange chromatography and pulsed amperometric detection (HPAEC-PAD DX-300, Dionex, USA) on an analytical Carbo-Pac PA1 column ( $4 \mathrm{x}$ $250 \mathrm{~mm})$ using a sodium acetate gradient $\left(1 \mathrm{~cm}^{3} \cdot \mathrm{min}^{-1}\right)$ in 150 mol. $\mathrm{m}^{-3} \mathrm{NaOH}$. The elution programme followed that of Itaya et al. (1997).
After deionization, the neutral carbohydrates (100 $\mu \mathrm{g}$ fructose-equivalents per lane) were also analyzed by ascending thin-layer chromatography (TLC) on silicagel plates (Silicagel 60, layer thickness $0.2 \mathrm{~mm}$, Merck or F1500, Schleicher and Schuell) and developed in butan-1-ol/ propan-2-ol/water (3:12:4, v:v:v) as solvent system (Kanaya et al., 1978). Fructose-containing sugars were visualized after spraying with the ketose-specific urea-phosphoric acid reagent (Wise et al., 1955). Extracts of tubers of Helianthus tuberosus and leaves of Lolium temulentum were used as reference material for different fructan series.

Differences in total sugar and fructose concentrations between the different tissues were identified by ANOVA analyses, followed by the multiple comparisons test of Student Newman Keuls.

\section{RESULTS AND DISCUSSION}

Most of the water soluble carbohydrates (WSC) in all parts of plants of Lolium multiflorum was composed of fructose polymers (figure 2), confirming previous information that fructans are the main reserve carbohydrates in this temperate forage grass (Souza et al., 2005), even when cultivated in a glasshouse under a subtropical environment.

In cool-season grasses, fructans are mainly accumulated in both leaf sheaths and elongating leaf bases. In Lolium perenne $64 \%$ of total fructans are stored in the leaf sheaths and $36 \%$ in the elongating leaf bases (Morvan et al., 1997). It has been suggested that sheaths serve predominantly as thoroughfares for carbohydrates between leaf blades and other parts of the plant (Borland and Farrar, 1988). When carbon is fixed in excess relative to the overall plant demand, assimilates are unloaded along the path and stored mainly as storage carbohydrates. Sheaths are then considered to function metabolically as a reservoir of nonstructural carbohydrates in plant species devoid of storage organs per se (Housley and Volenec, 1988).

In the present study, sheaths and elongating leaf bases were not extracted separately, so the extent to which carbohydrates were partitioned in these two tissues is not known. Both tissues were considered as part of the stubble (including the stem), and contained approximately three times the amount of total fructose found in leaves (figure 2). Griffith (1992) found high levels of soluble carbohydrates in stems of Lolium multiflorum Lam. var. Marshall, immediately after anthesis, in the early stages of seed growth. According to this author, under conditions of reduced photosynthetic capacity, the stem plays an important role in partitioning 


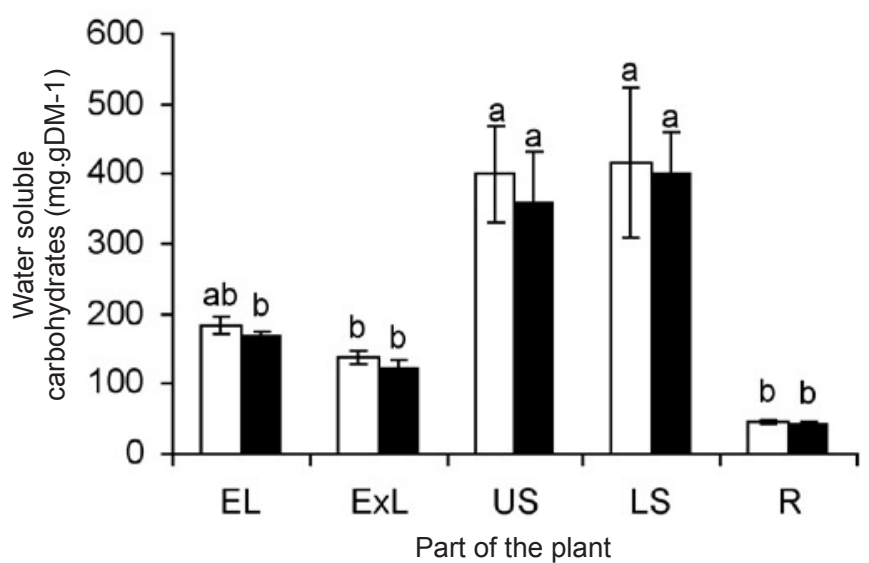

Figure 2. Total water soluble carbohydrates $(\square)$ and total fructose ( $\square$ ) contents in five different parts of plants of Lolium multiflorum grown for 4 months in the glasshouse: $\mathrm{EL}=$ elongating leaf blades; ExL = expanded leaf blades; US $=$ upper stubble; $\mathrm{LS}=$ lower stubble and $\mathrm{R}=$ roots. Letters compare total fructose or total sugar in different parts of the plant. Values indicated with the same letter are not statistically different $(\mathrm{p}<0.05)$. Bars indicate the standard error.

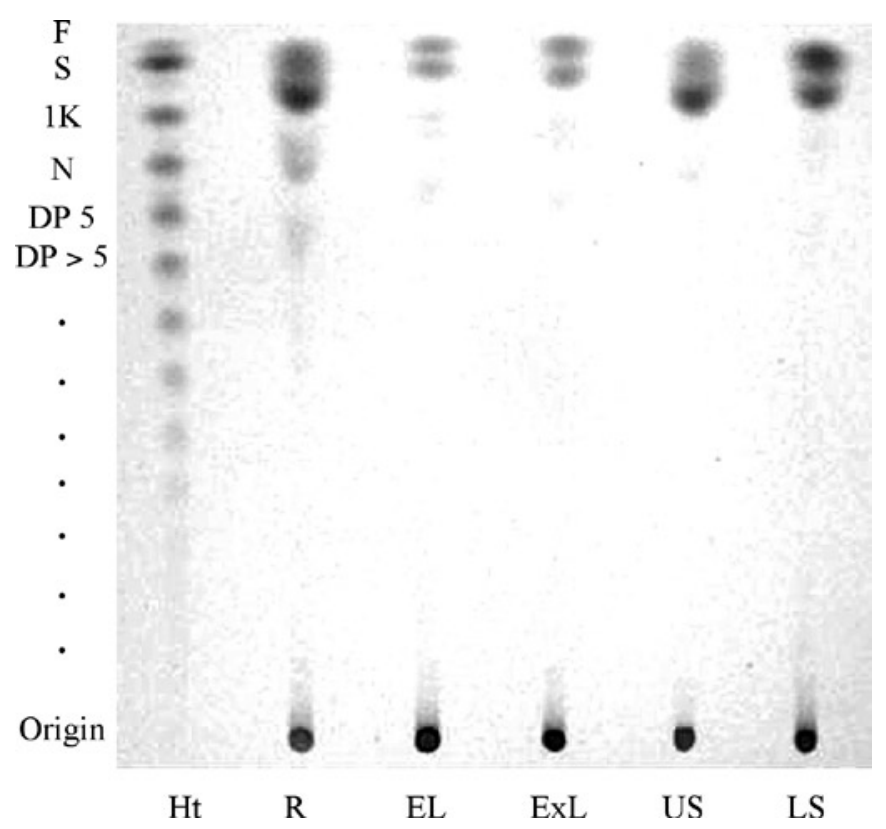

Figure 3. Thin layer chromatography (TLC) of water soluble carbohydrates in five different parts of plants of Lolium multiflorum grown for 4 months in the glasshouse: $\mathrm{R}=$ roots; $\mathrm{EL}=$ elongating leaf blades; $\mathrm{ExL}=$ expanded leaf blades; US = upper stubble and LS = lower stubble. Ht = fructo-oligosaccharides from tubers of Helianthus tuberosus (standard); $\mathrm{F}=$ fructose; $\mathrm{S}=$ sucrose; $1 \mathrm{~K}=1$ kestose; $\mathrm{N}=$ nystose; $\mathrm{DP} \geq 5=$ fructo-oligosaccharides of degree of polymerization $\geq 5$. Samples contained $80 \mu \mathrm{g}$ of total fructose. assimilates. In the present work, conditions of high moisture, light or fertilization, such as those found in the glasshouse, favored the production of assimilates and growth of new tillers (data not shown), which are considered strong sinks for assimilates according to Griffith (1992). Indeed, Pollock and Jones (1979) observed in the stems of varieties of Lolium perenne, Festuca pratensis and Phleum pratense at anthesis that the lower internodes accumulated the largest proportion of fructan. In contrast, in the present work no significant difference was found in the concentration of fructose polymers in both upper and lower parts of the stubble, since both parts included leaf bases of fully expanded leaves and whole or partial basal segments of elongating leaves. This result emphasizes the importance of these tissues as temporary reservoirs of long-term stored fructan (in mature tissues), and as short-term storage in the extension zones of growing leaves, to support plant regrowth when demand exceeds photoassimilate production, as pointed out for stems in other forage grasses (Pollock and Jones, 1979; Housley and Volenec, 1988).

No significant differences in total fructose were found in the elongating leaf blades in comparison with the expanded leaf blades (figure 2). In L. perenne, Guerrand et al. (1996) and Morvan-Bertrand et al. (1999) reported higher fructan contents in the elongating leaves than in expanded leaves. These results suggest that fructose polymers could have functions such as energy supply, unloading of sucrose from phloem and regulation of osmotic potential (Volenec, 1986; Cairns et al., 1991). The authors considered in their analysis whole expanding leaves and not only the leaf blade, as in the present study. Here, the stubble comprised the elongation zone and maturation zone of elongating leaves, both of which could act as strong sinks for photosynthates, presenting similar sink strength for incoming carbohydrates, regardless of the carbon source, which could be either the mature leaf blades or the elongating leaf blades (Allard and Nelson, 1991). So, under carbohydrate accumulation conditions, elongating leaf blades could have translocated the fixed $\mathrm{C}$ to the maturation zone, reducing the need for fructan as source of $\mathrm{C}$ for synthesis in that zone.

It is suggested that fructan accumulation in expanded leaves occurs just when the capacity of accumulation in the sheaths is reduced (Guerrand et al., 1996). According to Humphreys et al. (2006) this process can also be influenced by a number of environmental factors, including irradiance, temperature, water availability, etc. Guerrand et al. (1996) found that SST activity was highest in expanding leaves and 
lowest in mature leaf blades, resulting in higher levels of fructan in the first tissues.

Roots of L. multiflorum (figure 2) presented ten times less sugars than the stubble. This data is consistent with findings of McGrath (1988) who observed that roots of perennial and Italian ryegrass generally presented 5-10\% of fructan. Results obtained in this work suggest that the conditions prevailing in the glasshouse promoted growth of the aerial organs of the plants and decreased the accumulation of fructans in the underground organs (roots). Therefore, the accumulation of carbohydrates in the leaf sheaths seems to be more important for plant development than accumulation in the roots.

Fructan polymers of varying sizes were present in extracts obtained from all analyzed organs of L. multiflorum. TLC analysis showed faint spots of low DP fructans and strong spots of high DP fructans on the baseline (figure $3)$. Carbohydrates with a degree of polymerization higher than three were observed mainly in the roots, while monosaccharides and sucrose predominated throughout the other parts of the plants but in lower proportions in the elongating and in the expanded leaf blades. Similarly, Pavis et al. (2001a) found the highest level of low molecular weight fructans in the roots of $L$. perenne, when compared to other parts of the plant.

Considerable variations have been reported in the proportion of individual chain size fructans between fructanstoring grass species (Chatterton et al., 1990), but variations can also exist among different tissues of the same plant. The outer leaf sheath of tall fescue, for example, contained significantly more DP $>6$ fructans and less DP 3-6 fructans than the expanding leaves (Housley and Volenec, 1988). In the present work, the HPLC analyses showed high proportions of low DP fructans, eluted between 5 and 10 min., in all parts of the plants, but especially in the roots (figure 4). The high proportion of low- to high-DP fructans was similar in both upper and lower parts of the stubble and similar to results obtained for other grass varieties (Pollock and Jones, 1979). This means that the fructan content of these tissues includes both longer-term stored fructan in mature tissues and the very labile fructan accumulated in the extension zones of growing leaves, as previously discussed. However, higher proportions of fructans of all sizes were found in basal segments of the stem of L. perenne (Pavis et al., 2001b). Sheen (1994) suggested that accumulation of fixed carbon as fructan in leaf bases prior to storing in tissues closer to the blades and sheaths (or stubble) might also allow photosynthesis in blades to proceed by avoiding sugar-induced feedback inhibition.

In relation to the leaves, figure 4 shows higher proportions of low and intermediate DP fructans in the elongating leaf blades than in the mature ones. Similar trends were observed by Guerrand et al. (1996) and Pavis et al. (2001b) in plants of L. perenne and were related with the high demand for energy by the expanding leaves. According to the first authors, low DP fructans could be more readily mobilized during regrowth of new shoots. Besides, the expanded leaves contain the oldest cells, which were probably already senescing and therefore less active in terms of $\mathrm{C}$ fixation (Pavis et al., 2001b), and presented small proportions of low DP fructans. The considerable proportion of high DP fructans in mature leaf blades, in comparison with the elongating leaf blades (figures 4A and 4B) is consistent with the role of long-term reserve carbohydrate.

High contents of water soluble carbohydrates present in the vegetative tissues of $L$. multiflorum is an important feature concerning cattle nutrition consistent with its common use as forage. In Brazil, Italian ryegrass represents more than $80 \%$ of the pasture composition during winter season in lowland areas of Rio Grande do Sul State (Marchezan et al. 2002). Storage carbohydrates either as free sugar or as polysaccharide, provide metabolic energy and are sources of carbon skeletons for general biosynthesis for cattle (Humphreys et al., 2006). Indeed, sucrose and fructans constitute the most important fermentable carbohydrate fraction (70-80\% of the total) in vegetative tissues (Pollock and Cairns, 1991; Cairns et al., 2002). During grazing, the leaves are the main organ removed by the animals, while the stubble (including the stem) and the roots remain in the soil and contribute with their reserves of water soluble carbohydrates to the new growing shoots for re-establishment of photosynthetic capacity (Fulkerson and Donaghy, 2001).

Considering that leaves of forage grasses constitute the main component of cattle feed and that higher contents of soluble carbohydrates were present in the stubble, followed by elongating leaf blades, expanded leaf blades and roots, it is plausible to suppose, from a quantitative and qualitative point of view, that cattle receive a low source of energy when eating leaves. These data are in agreement with other work concerning L. perenne plants in which higher fructan accumulation was found in sheaths, followed by expanding leaves and finally by blades (Guerrand et al., 1996). In addition, Pavis et al. (2001b) reported high contents of sucrose and low contents of fructans in the distal part of the leaf blade for the same species. 

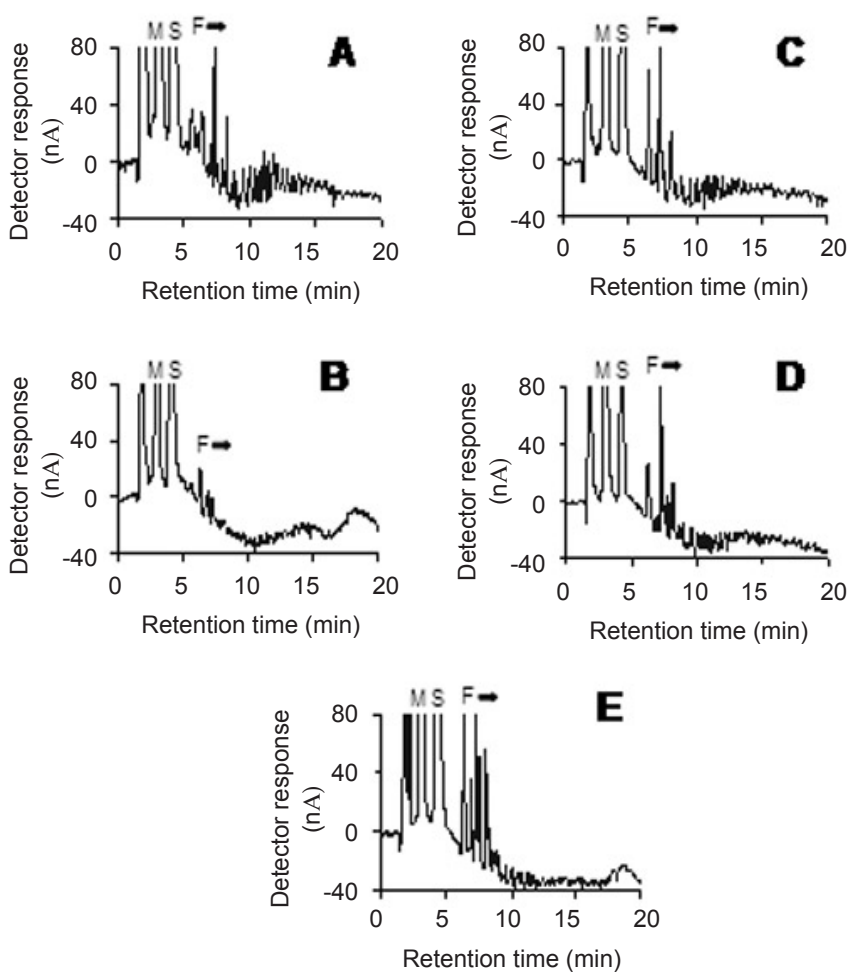

Figure 4. Analysis by HPAEC/PAD of soluble carbohydrates in five different parts of plants of Lolium multiflorum grown for 4 months in the glasshouse: $\mathrm{A}=$ elongating leaf blades; $\mathrm{B}=$ expanded leaf blades; $\mathrm{C}=$ upper stubble; $\mathrm{D}=$ lower stubble and $\mathrm{E}=$ roots. Carbohydrates were identified by comparison with standards of known retention time. M: monosacharides; S: sucrose; F: fructans. Samples contained $800 \mu \mathrm{g}$ fructose equivalente $/ \mathrm{mL}$.

It is well known that Lolium species are very sensitive to abiotic stresses (Humphreys et al., 2006). So, the presence of fructans of different sizes in different tissues of plants of L. multiflorum growing under appropriate subtropical environmental conditions should be taken into account to understanding physiological responses of plants growing under the stress conditions of polluted sites. The capacity to accumulate toxic elements from the air and the biomonitoring efficiency of the studied cultivar may also be affected since their concentrations are expressed relative to leaf matter.

Acknowledgments: This work is part of the $\mathrm{PhD}$ thesis of the first author and supported by FAPESP (Proc. 00/06422-4). C.Z. Sandrin thanks CAPES for the PhD fellowship. R.C.L. Figueiredo-Ribeiro and M. Domingos are research fellows of CNPq. The authors also thank Dr Maria Angela M. Carvalho for the critical review of the manuscript.

\section{REFERENCES}

Allard G, Nelson CJ (1991) Photosynthate partitioning in basal zones of tall fescue leaf blades. Plant Physiol. 95: 663-668.

Arndt U, Schweizer B (1991) The use of bioindicators for environmental monitoring in tropical and subtropical countries. In: Ellenberg H, Arndt V, Bretthauer R, Ruthsatz $\mathrm{B}$, Stenbing L (eds), Biological monitoring - signals from the environment, pp.199-260. Eschborn, Vieweg.

Bonnett GD, Sims IM, St John JA, Simpson RJ (1994) Purification and characterization of fructans with $\beta-2,1-$ and $\beta$-2,6-glycosidic linkages suitable for enzyme studies. New Phytol. 127:261-267.

Borland AM, Farrar JF (1988) Compartment and fluxes of carbon in leaf blades and leaf sheaths of Poa annua L. \& Poa $\mathrm{x}$ jemtlandica (Almq.) Richt. Plant Cell Environ. 11: 535-543.

Cairns AJ, Winters A, Pollock CJ, Nelson CJ, Schnyder H, Allard G (1991) Fructan metabolism in leaves of temperate grasses. In: Bonnemain JL, Delrot S, Lucas WJ, Dainty J (eds.), Phloem Transport and Assimilate Compartmentation, pp.33-40. Ouest Editions, Presses Académiques, Nantes, France.

Cairns AJ, Begley P, Sims IM (2002) The structure of starch from seeds and leaves of the fructan-accumulating ryegrass, Lolium temulentum L. J. Plant Physiol. 159:221-230.

Chatterton NJ, Harrison PA, Thornley WR, Draper EA (1990) Oligosaccharides in foliage of Agropyron, Bromus, Dactylis, Festuca, Lolium and Phleum. New Phytol. 114:167-171.

Domingos M, Klumpp A, Klumpp G (1998) Air pollution impact on the Atlantic forest in the Cubatão region, SP, Brazil. Ciência e Cultura 50:230-236.

Dubois M, Gilles A, Hamilton JK, Rebers PA, Smith F (1956) Colorimetric method for determination of sugars and related substances. Anal. Chem. 28:350-355.

Epstein E (1975) Nutrição mineral das plantas. Princípios e perspectivas. Editora da Universidade de São Paulo/Livros Técnicos e Científicos Editora S.A., Rio de Janeiro.

Fulkerson WJ, Donaghy DJ (2001) Plant-soluble carbohydrate reserves and senescence - key criteria for developing an effective grazing management system for ryegrass-based pastures: a review. Aust. J. Exp. Agric. 41:261-275.

Griffith SM (1992) Changes in post-anthesis assimilates in stem and spike components of italian ryegrass (Lolium multiflorum Lam.). I. Water soluble carbohydrates. Ann. Bot. 69:243-248.

Guerrand D, Prud'homme MP, Boucaud J (1996) Fructan metabolism in expanding leaves, mature leaf sheaths and mature leaf blades of Lolium perenne. Fructan synthesis, fructosyltransferase and invertase activities. New Phytol. 134:205-214.

Housley TL, Volenec JJ (1988) Fructan content and synthesis in leaf tissue of Festuca arundinacea. Plant Physiol. 86: 1247-1251. 
Humphreys MW, Yadav RS, Cairns AJ, Turner LB, Humphreys J, Skot L (2006) A changing climate for grassland research. New Phytol. 169:9-26.

Itaya NM, Buckeridge MS, Figueiredo-Ribeiro RCL (1997) Biosynthesis in vitro of high-molecular mass fructan by cell-free extracts from tuberous roots of Viguiera discolor (Asteraceae). New Phytol. 136:53-60.

Jermyn MA (1956) A new method for the determination of ketohexoses in the presence of aldohexoses. Nature 177: 38-39.

Kanaya KI, Chiba S, Shimomura T (1978) Thin layer chromatography of linear oligosaccharides. Agric. Biol. Chem. 42:1947-1948.

Marchezan E, Vizzoto VR, Rocha MG, Moojen EL, Silva JHS (2002) Produção animal em várzea sistematizada cultivada com forrageiras de estação fria submetidas a diferentes níveis de adubação. Ciência Rural 32:303-308.

Mc Grath D (1988) Seasonal variation in the water-soluble carbohydrates of perennial and Italian ryegrass under cutting conditions. Irish J. Agric. Res. 27:131-139.

Morvan A, Challe G, Prud'homme MP, Le Saos J, Boucaud J (1997) Rise of fructan exohydrolase activity in stubble of Lolium perenne after defoliation is decreased by uniconazole, an inhibitor of the biosynthesis of gibberellins. New Phytol. 136:81-88.

Morvan-Bertrand A, Pavis N, Boucaud J, Prud'homme MP (1999) Partitioning of reserve and newly assimilated carbon in roots and leaf tissues of Lolium perenne during regrowth after defoliation: assessment by ${ }^{13} \mathrm{C}$ steady-state labelling and carbohydrate analysis. Plant Cell Environ. 22:1097-1108.

Morvan-Bertrand A, Boucaud J, Le Saos J, Prud'homme MP (2001) Roles of the fructans from leaf sheaths and from the elongating leaf bases in the regrowth following defoliation of Lolium perenne L. Planta 213:109-120.

Pavis N, Boucaud J, Prud'homme MP (2001a) Fructans and fructan-metabolizing enzymes in leaves of Lolium perenne. New Phytol. 150:97-109.

Pavis N, Chatterton NJ, Harrison PA, Baumgartner S, Praznik W, Boucaud J, Prud'homme MP (2001b) Structure of fructans in roots and leaf tissues of Lolium perenne. New Phytol. 150:83-95.

Pollock CJ, Jones T (1979) Seasonal patterns of fructan metabolism in forage grasses. New Phytol. 83:9-15.

Pollock CJ, Cairns AJ (1991) Fructan metabolism in grasses and cereals. Annu. Rev. Plant Physiol. Mol. Biol. 42:77-101.

Roth A, Lüscher M, Sprenger N, Boller T, Wiemken A (1997) Fructan and fructan-metabolizing enzymes in the growth zone of barley leaves. New Phytol. 136:73-79.

Sandrin CZ, Domingos M, Figueiredo-Ribeiro RCL (2004) Fructan changes in Lolium multiflorum ssp. italicum "Lema" as an indicator of urban air pollution. In: Klumpp A, Ansel W, Klumpp G (eds), Urban Air Pollution, Bioindication and Environmental Awareness, pp.293-301. Cuvillier Verlag, Gottingen, German.

Sheen J (1994) Feedback control of gene expression. Photosynth. Res. 39:427-438.

Schnyder H, Nelson CJ (1987) Growth rates and carbohydrate fluxes within the elongation zone of tall fescue leaf blades. Plant Physiol. 85:548-553.

Smouter H, Simpson RJ (1991) Fructan metabolism in leaves of Lolium rigidum Gaudin II. Fructosyltransferase, invertase and fructan hydrolase activity. New Phytol. 119:517-526.

Souza A, Sandrin CZ, Moraes MG, Figueiredo-Ribeiro RCL (2005) Diurnal variations of non-structural carbohydrates in vegetative tissues of Melinis minutiflora, Echinolaena inflexa and Lolium multiflorum (Poaceae). Rev. Bras. Bot. 28:755-763.

Spollen WG, Nelson CJ (1994) Response of fructan to water deficit in growing leaves of tall fescue. Plant Physiol. 106: 329-336.

Thomas H, James AR (1999) Partitioning of sugars in Lolium perenne (perennial ryegrass) during drought and on rewatering. New Phytol. 142:292-305.

Volenec JJ (1986) Nonstructural carbohydrates in stem base components of tall fescue during regrowth. Crop Sci. 26: 122-127.

Wise CS, Dimler RJ, Davies HA, Rirst CE (1955) Determination of easily hydrolyzable fructose units in dextran preparations. Anal. Chem. 27:33-36. 